\title{
Abandoned Hungarian workers and the political economy of care work in Austria
}

\author{
Attila Melegh - Dóra Gábriel - Gabriella Gresits - \\ Dalma Hámos ${ }^{1}$
}

https://doi.org/10.51624/SzocSzemle.2018.4.3

Manuscript received: 30 August 2018.

Modified manuscript received: 19 December 2018.

Acceptance of manuscript for publication: 21 December 2018.

\begin{abstract}
In an era of globalization, the institutional system of mass migration is being substantially reorganized: its intensity and the variation in its forms are increasing. Global production chains combine diverse areas and different forms of work with varying wage levels by forming worldwide networks. In the Eastern European region, the growing level of emigration and relatively low fertility are leading to population loss. Hungary is not among the Eastern European countries with a high level of emigration; nevertheless, it faces serious challenges, particularly in some regions where after the transition losses of jobs were massive, and a greater proportion of people live under the poverty line than the national average. Our analysis is based on interviews, containing narrative and semi-structured parts, among domestic workers working mainly in Austria and Germany. The paper reveals possible causal mechanisms and the political economic structures behind this type of labour migration. We seek to understand how migrationrelated decisions are embedded in a global and highly unequal economic order.
\end{abstract}

Keywords: labor migration, rational choice, historical-structural analysis, domestic work, working class

In an era of globalization, the institutional system of mass migration has become substantially reorganized and its intensity and variation are increasing. Globalization can be interpreted as a cycle of capitalism in which the increasing freedom of movement of capital maintains free trade, which in turn enables mechanisms of reproduction that in turn reorganize global manufacturing and service industries and move them to new territories. As a part of this process, global production chains combine diverse areas and different forms of work with varying wage levels within worldwide networks. In addition, the freer movement of capital and labour also affects welfare and social systems by depreciating and partly eliminating welfare services and

1 The research this paper refers to was carried out by a research group within the frame of the Hungarian Demographic Research Institute (HDRI). The field work, the interviewing, and the related research were managed and to a very large extent performed by Dóra Gábriel who published key results of the research in a HDRI Research Report (Gábriel 2018). The professional leader of the research was Attila Melegh, who wrote the below text based on his own analysis of the interviews, and from new analytical perspectives Gabriella Gresits contributed to this text through her specific analysis and together with Dalma Hámos participated in the research and analysis through her work on the narratives and biographies in the interviews. 
"surplus" wages (i.e. rents) in the case of richer Western nations/societies, as well as the socialist Eastern Bloc. In the frame of a neoclassical macro theory of migration, Szelényi and Mihályi, for instance, argue that migration has facilitated the reduction of "rents" (i.e. unearned income of individuals due to privileged global positions) from European workers. At the same time, these geographical areas have been significantly transformed demographically. Since the 1980s, Western and Southern Europe has counterbalanced low levels of fertility by increasing migration rates. In opposition to this tendency, in Eastern Europe growing levels of emigration and a rapidly aging population coupled with relatively low fertility rates are all contributing to population loss. It is highly likely that a demographic crisis will evolve given that in certain countries the active population will not or will hardly exceed the number of people born in the country but living abroad and the number of dependent elderly people. Thus, Western European governments that are anxious about maintaining welfare services are seeking well specific working populations for their corporate spheres by extracting migrant labour from areas that themselves face major demographic problems (Melegh 2016, 2017). As a result of this, new cycles are opening up in the global economy in which wage differentials play a very important role.

Hungary is not among the countries with very high levels of emigration in Eastern Europe (according to the UN, almost 7 percent of the population born in Hungary live outside the country; UN 2017); nevertheless, it faces serious challenges, particularly in those regions where after the transition job losses were massive and more individuals live below the poverty line than the national average. The targeted area of our research, Baranya County in Southern Transdanubia, is one such deprived region. Its industrial capacity - mines, the main manufacturing enterprises, and textile plants - have been closed down and have not been replaced by more significant industry, as opposed to, for instance, the Northern regions of Transdanubia. According to the regional inequality indicators, a major part of the region is seriously disadvantaged, and faces social problems related to poverty and employment (Obádovics et al. 2011).

\section{The research problems and related theoretical frameworks}

The present analysis is based on interviews with narrative and semi-structured parts conducted among domestic workers who work abroad. These people count as shortterm circular migrants as most have spent more than three months abroad at least once, their gainful and principal employment is abroad, and they have left and returned to Hungary several times, with a cumulative time living abroad exceeding a year and, in some cases, even years (UN 2016). Thus, they constantly live in a transnational space, albeit without giving up their stable residence at home. It is also important to note that these migrants are the older age groups of the potentially active workforce, and in some cases are even beyond retirement age. Thus they also represent the phenomenon of "care drain" as they are not available to take care of other family 
members. They are also people who face the relatively high risk of not finding a job due to their age. Thus, our group is rather special in the sense that they represent a somewhat specific group of circular migrants who are not younger members of the workforce, unlike most other migrants. (Blaskó - Gödri 2014)

In order to reveal the potential causal mechanisms and links to political economic structures behind these forms of labour migration through the analysis of interviews, we need to clarify what theoretical and methodological frameworks are appropriate for this purpose. In this analysis we argue that in the case of such types of circular migration, we need to utilize various perspectives (household economics, and the role of historical macrostructural factors) to understand the complexity of the process as presented by individuals and families. We also claim that in these complex and historically contextualized processes, neoclassical, micro-level rational decision-making is just one, specific perspective that is associated with specific conditions if interviews are analyzed. We also investigate what structural factors and what elements in the life histories of interviewees might have led them to construct their perspectives.

Throughout the research, one of our main goals was to reveal how care worker interviewees who come from a relatively depressed region present their decisions in a complex way in qualitative interviews about their life histories. We were particularly interested in how the global and highly unequal economic order appeared in these texts and narratives (Parreñas 2011, Sarkar 2017). Moreover, we were eager to see under which conditions the individual stories of care workers actually fit the rational choice framework, and when they opt for work abroad.

In doing so first, let us clarify how the approach of rational individuals can be operationalized and criticized and how this issue is described in the Hungarian literature on emigration, especially concerning the migration of domestic workers. According to Massey and his colleagues, the basic assumptions of micro-level neoclassical theory are the following (Massey et al. 1993): "Costs" should not exceed "profits" in the long term; migrants are required to make individual decisions on the basis of expected individual benefits. In addition, it is necessary for them to have information not only about the cost of being abroad and wages in the target country, but also to realize and evaluate the total cost of migration at home. The total cost should include all material and non-material costs (including "forgotten" material costs, the extra costs of family members left behind, the costs of emotional distress), and such circular migrants should strive to maximize profitability in the long-term. They also have to choose a country according to these rational calculations. Thus, in the interviews we looked for evidence (ideas and formulas) in migrant workers' argumentation that they had engaged in such general calculations. We also examined in which interviews this phenomenon occurred and in which interviews it did not, and in what contexts.

The theory of rational choice has been widely criticized by researchers. According to Portes and Böröcz, it involves a post-factum approach that cannot explain the 
degree and direction of migration between individual countries and differences in the willingness of individuals, at least in the sense that we cannot predict migration in cases of similar benefits (Portes - Böröcz 1989). In the criticism put forward in the theory of the new economics of labour migration, the emphasis is placed on the fact that migratory decisions are not made by isolated individuals, but by households and families who, through a wide range of activities, try to minimize risks and pool incomes from different sources. Very importantly, the household economic approach also argues that the gains of migration are much less decisive and much smaller in reality than expected (Massey et al. 1993; see also Szelényi 2016). Thus during our analysis we made a special effort to cross-check the calculations of the interviewees (in the form of a complex Excel sheet containing data about costs and benefits) and to identify which cost elements were mentioned and which elements were "forgotten" in order to analyze calculations beyond data about wages.

In thinking about actual cost-benefit calculations, we should also point out that joint family activities can have micro-economic consequences; namely, certain familial work and social activities do not have a price and thus cannot be taken into account as wages or costs. Thus, instead of maximizing "profit," a family may follow inner feelings about "self-exploitation," as Alexandr Chayanov specified in the 1920s (Chayanov 1966). It should be noted that the relationship between these Chayanovian insights and the new economics of labour migration has not been systematically utilized yet. All of these analytical perspectives deal with "forgetting," and partly "hiding" costs (see Nagy et al. 2012). Costs may be hidden because the additional family labour of maintaining a household strategy is not counted as a wage or cost, thus in this microeconomic frame it is not possible to calculate "net profit," thus a feeling of being exploited may guide economic-migratory manoeuvring. All these considerations are extremely important to us, thus we sought to identify in our interviews when this feeling of making a "sacrifice for the family" occurred, and how it was related to interviewees' life histories.

Concerning joint familial decision-making, in a novel way we also used Tamara K. Hareven's notions of the conjunction between individual, family, and industrial cycles, according to which decisions are not born only as part of an individual cycle, but the family life cycle also plays an important role by interacting with the industrial cycle - namely, with wider cycles of economic requirements and necessities (Hareven 1982). The huge role of family and household decision-making mechanisms has also been widely demonstrated historically and over geographically wide areas (McKeown 2004, Stark - Bloom 1985). Following these considerations, these life cyclical linkages were also observed in interviews when we analyzed how the life cycles and biographies of family members were interlinked with the life histories of the families and macrostructural changes. For instance, we analyzed how individual events affected family life, and how work abroad fitted into these developments. One example of this is the labour migration of a female partner after a male partner becomes sick or loses 
his job during an economic transition. We also analyzed in which cases do linkages between various life cycles become evident.

Beyond micro theories, there is also a need to look at macro-level changes, and how they are incorporated in the interview texts and individual life histories and whether they are used as an alternative to rational familial and/or individual decisionmaking, even over a longer time period. World system theory emphasizes the external environment and its systemic change in its criticism of neoclassical frameworks. This we consider important because, as a prerequisite of migration, it emphasizes that world economic impacts (such as the collapse of socialist industry) must first uproot people from their "traditional" lifestyles, and that some of those who are thus affected will leave (Sassen 1988, Melegh 2013, Melegh 2015). In our analytical perspective the mention of macrostructural changes and historical links by interviewees cannot be ignored during the exploration of possible chains of causality in the interview texts. In other words, we also sought to look at particular and historically evolving social relations that produce the conditions among which individuals manoeuvre, and thus make migration highly likely, and how this phenomenon appears in interview texts. We also analyzed in what interview texts and in what circumstances these linkages arise.

The Hungarian literature on emigration tends to accept the rational choice hypothesis in terms of longer term migration (Blaskó - Gödri 2014, Hárs - Simon 2015) although scholars who work on the migration of domestic labour emphasize additional factors.

After conducting an analysis of the short-term, cyclical migration of domestic workers, Váradi and her colleagues came to a partially different conclusion (Váradi et al. 2017). The authors believe rational considerations are important, but they also emphasize the relationship between agency and structure, and the role of "forced" decisions. They argue that life situations make the combinations of aspirations and capabilities specific, and emphasize the role of networks.

In her complex analysis Turai refers to the links between individual and family cycles and the role of the economic decisions of a family in her research based on more than 200 interviews conducted among domestic labour migrants from Hungary, Romania and Moldova. It is worth citing here a longer argument of hers that indicates the complexity of causality which includes an assessment of what motivations are seen as legitimate:

Concerning the causal mechanisms of migration, mostly material motivations are visible or they are made visible. Livelihood constraints, unemployment, debt, housing, and home purchase are economic needs that play an important role in the decision of the family to incorporate migration into their future strategies. [...] Financing children's higher education, family reunion, wedding, nesting, repayment of foreign currency loans, purchase of cars, supporting grandchildren etc. are strong arguments for participating in the global labour market. However, it has become obvious during the fieldwork that the mention of these causes is strongly related to their social 
legitimacy. In the social acceptance of migration, financial problems are seen as legitimate factors: if somewhere material problems emerge, action becomes necessary and positive content is associated with those [who act]. Financial problems can also derive from non-material family crisis situations. The reduced working capacity of the spouse, a broken partnership, or an inadequate contribution from an alcoholdependent husband to living costs are such situations in which women have to cope with extra burdens. Divorce, the burdens of one-parent households, and housing problems put extra burdens on certain segments of society who have limited access to resources anyway. Private affairs without material consequences are also part of mobility motivations. Foreign absence can temporarily solve a permanently disorderly and chaotic partnership situation in a social environment where divorce is negatively evaluated or when there is family pressure not to do so or a husband's aggression rules it out. (Turai 2018: 151-152)

Based on the above considerations, in the analysis below we focus on these issues and explain how the historically determined, gendered political economy of reproductive work is viewed and understood by the interviewed group (Parreñas 2001, 61-79, Turai 2018).

\section{Research methods}

The empirical research took place between March and August 2016. The research involved 21 interviews ${ }^{2}$ in total. Following the theoretical and methodological approach of the FEMAGE project (Kovács - Melegh 2007), we applied a combined interview technique. At the beginning of the interviews, we asked the respondents to tell us their stories of how they became caregivers. Afterwards, we asked them to talk more about those biographical elements that were not narrated in a detailed manner. The narrative part of the interview was followed by a semi-structural part that addressed issues relating to studies, previous work, family background, the decisionmaking process of migration, working abroad, wages abroad, social status and future plans. The period of interviewing was influenced by the so-called refugee crisis in 2015 and 2016, accompanied by a powerful socio-political debate; thus, we included questions related to opinions about the arrival of asylum seekers in our interview guide. The interviews were analyzed using the method of objective hermeneutics, namely, we systematically reconstructed the structure of interviewees' life histories based on the first narration (to see the key structures of self-representation and the complex motivational aspects freely presented), and then we carried out analysis also based on biographical elements (Rosenthal 1993, Kovács - Melegh 2000). For the later analysis we used the information found in the narratives and also in the structured parts of the interview to identify the types of such biographies.

2 For information about the respondents, see Table 1. Interviews were conducted by Diána Árki, Dalma Hámos, Dóra Gábriel, Gabriella Gresits, Attila Pirmajer and Eszter Ungi-Nagy. 
We also conducted four partner interviews. At the beginning of these interviews, the partners of care workers were asked to relate the stories of how their partners/ spouses had became care workers abroad, and then we used the same structural interview guide. In interviewing partners we wanted to address the issue of how "leftbehind" relatives interpret and narrate the familial aspects of migratory decisions. An interview was also carried out with a labour migrant who later established an agency for the foreign employment of care workers, which gave us insights into the functioning of the relevant labour-market segment from the point of view of an agent, the role of whom is becoming crucial in building migration infrastructure (Xiao-Lindquist 2014).

Our fieldsite was Baranya County, chosen not only due to the fact that it is an economically depressed region of the country, but also due to the Swabian ethnic groups living in some of its areas. We assumed that in this part of the country, based on the presence of a long-standing ethnic network, the number of elderly care workers commuting to Austria and Germany would be numerically higher. We applied the snowball method to identify our respondents.

\section{Wages and benefits}

Concerning the motivation for migration, the most common claim is that it is worth working abroad due to the wage differentials. Looking at the interview texts closely, we can see that after all social and pension contributions and travel expenses are covered, the interviewees earn approximately 600-800 euros of net income per month in the given migratory space (see Appendix 2). This amount is typically earned through shift work (the time of which generally increases as time spent in this career increases). ${ }^{3}$ It is very important to note that respondents mention their daily wage for the shift period, but very often it is only revealed later that the stated amount also includes the period they are at home. Anna, ${ }^{4}$ for example, proudly says that she earns "57 euros" or "17,000 forints" daily, but if we do all the calculations, including deducting travel expenses and social insurance, her net monthly salary is about 450500 euros. In the case of Anna, a lower-class Roma woman, this illusion of higher earnings can be interpreted as her having a hierarchical expectation of work in the "West" that legitimizes her leaving. Moreover, the feeling can be also perceived that she, as a lower-class rural person and a Roma woman, was also able to achieve financial success (Durst 2013, 210, 217-220).

It should be noted that the initial wage or retirement/social benefits in Hungary that our interviewees received (if any) was usually worth 150-300 euros, so the 600900 euros (converted into a monthly amount), and the frequently mentioned 700-

3 In other cases, they work in monthly shifts and earn proportionally more. However, the increase in salary must also include budgeting for a whole month of staying at home between shifts, and must cover regular (housing) expenses when migrants are abroad.

4 For detailed information concerning the wages and expenses of the respondents, see Table 2. 
euro salary of a care worker (including accompanying meals) is significantly higher. In this respect, the neoclassical expectation of wage differentials playing a crucial role in this migratory space prevails according to the interviews. However, the migration process and its political economy are far more complicated, and ignoring the other factors creates a misleading picture. This is why it is worth carrying out a more complex analysis to fully understand this mass social action, the related social relationships, and their historical and structural determination.

One of the most interesting observations from the interviews is that people talked positively and openly about wage and non-material benefits in their narratives when their background and work careers were stable. ${ }^{5}$ Such interviewees opted for migration very often after retirement, and they evaluated the available opportunities positively. This is how Lídia explained her decision:

Well, after retirement, then after three weeks? ... I said that being constantly at home is so tedious, all the domestic work. And then I decided once to try it - either it would work or not... It is not just about the money. It also motivates me, as you can help the grandchildren more, but the work itself and the beautiful places, and it's not so boring when one comes home for two weeks, then it's different again, different here and different there. There are also nice and good things there, and at home too. I like doing it. Really. (Lídia, 67)

It is important to notice that in this case we do not simply see the story of an individual seeking to maximize her income, but the story of an aging but vigorous grandmother, already with stable living conditions, who mainly wants to help her grandchildren. However, even in her case we can identify factors that go far beyond the neoclassical framework. Both her and her husband's Swabian origins played a major role in their foreign labour, such as the husband's formerly (ethnic-kinorganized) period of work as a stonemason in Germany. The following case also shows the complexity of the problem, and the necessity of the integration of new factors and analytical levels.

A former hairdresser, Csenge, states very firmly that she had a very low salary at home, which is why she had to leave. However, her income considerably increased after commuting abroad:

Good. So, in fact, I came out to Germany because I was working as a hairdresser and we were earning very little. The more clients we had, the less we were earning... And then I went to work in the vocational school, to the kitchen, and the work was very hard there too, and everything, and, well, I thought that many people go abroad, I should try. And I tried, and I got an extraordinarily good job, I was there for six months, but not like six months in a row, but two months there and two months here, because my husband was at home and he was sick and that's why I had to come

5 Somewhat similar observations have been made by Váradi et al. 2017, who emphasized that young people see migration as an opportunity. It is not clear though if the same perspective would remain after a longer period of struggling to find a job. 
home. I was well paid, of course, compared to what I earned at the hairdresser's, five times, ten times more, if I can say that. (Csenge, 74)

The interviewee exaggerates when she says that her new salary of 600-700 euros per month was five or ten times more than her original salary, but clearly it increased considerably. She started her job after having retired, during which time her earlier period of work (which lasted for 35 years) was gradually devalued in terms of income, and her salary even diminished towards the end of her career. This latter factor also affected her retirement income. Thus, the structural transformation (as we return to later, involving the devaluation of the related service sector) had a significant impact on the course of her life. In addition, her husband's illness and his relatively quick death at the beginning of the migration process could also have represented a financial crisis which increased her willingness to migrate, or maintained it. However, it is important to note that Csenge was in a stable situation and was able to experiment, not being in real need. Perhaps this might be one of the perspectives that can be employed when attempting to describe wage differentials clearly. It can be hypothesized that some interviewees talk about "profit maximization" and "utilizing wage differentials" who choose to migrate among relatively stable circumstances.

Another perspective arises: when a crisis occurs, and then this social action will have a different meaning. A widow, Beáta, does not mention wages.

The interviewee starts her story by talking about a period of unemployment and migration after a longer period of struggle, thus in principle her narrative accords with the neoclassical theoretical perspective, as she was significantly able to improve her situation. Meanwhile, we should see that her work history reveals long-lasting efforts to find a stable job, and note that Beáta had only short-term jobs, which may indicate that her migration in 2009 was not only the result of a quick decision; she had to be uprooted first. Beáta's daughter also went abroad in the same year. This was probably a coordinated crisis measure that did not reflect the respondent's income maximizing intentions as she did not really want to go, but she found she had to give up "home". Moreover, the main concern for her was occupational security. In her narrative she is truly disappointed, and specifies that job stability was a crucial factor in her migration narrative.

I think it came when (I was) unemployed. Or... not for the first time. So you do not know what to do. Yes, if at home I had a job that fitted me, I'm sure that I would not go away. And that's what I say, until this day I say that if I could get a job at home that was certain... but you cannot find it in this world, I'm sure, I do not believe in this anymore. To be at home... sure. This option has already gone for me. (Beáta, 56)

For this group of cyclical labour migrants who were socialized under state socialism the security of jobs was important. This preference is also consistent with the fact that in Hungary the general appreciation of job security was higher than that of wage security among manual workers (Burawoy 1987). The disappearance of this 
security may be a factor behind mass migration, which is evaluated negatively by the interviewees.

The motivation of avoiding working for low wages is also present in an interview with an unskilled worker, Anna, as mentioned above.

Nonetheless, when analyzing the rather long first narrative closely and carefully tracing all the follow-up answers, we find that her motivation includes a lot more factors involving pressure for a longer period of time. Also, according to an interview with her husband, who started the narrative interview by mentioning these elements, one of the most important factors is that the family started a small business during the transition from state socialism. After the breakup of the collective farm, they failed in this entrepreneurial attempt, which led them into serious debt. This debt was further increased by various members of the family who had entered into a very serious debt trap by the end of the 2000s. The crisis was further deepened by the serious illness of the husband, which led to his dismissal and receipt of a disability pension. So the change of regime resulted in breaking point, after which loans covered the gap between incomes and needs for a while. The job in Austria has actually consolidated a longer-term crisis, thus the process is an extended one. Anna also explicitly raises the issue of the reference point for wage differences, since while the wage advantage exists today, the interviewee did not consider it valid; the salary from the poultry processing industry in the 1980s was the best she had:

Yes, yes. In the poultry processing plant, because they sent people away. There were three shifts there. From 6 a.m. - 2 p.m, from 2 p.m - 10 p.m, and from 10 p.m. - 6 a.m. in the morning. We had to work in three shifts. But it was good. That wage was worth more than any you can get now. It was better than anything, since because its [relative] value was greater. (Anna, 53)

The devaluation of the wage advantage in the above-mentioned example also occurs in many other cases, such as in the case of Katinka. Katinka can also see that instead of the 100 euros payment for public work in Hungary, the monthly salary of 400-450 euros she earns while abroad is a major step forward, which she accepted because her son who lives at home does not have an income. It is an important consideration nonetheless that she perceives her migration as being forced, and finds the cost of it to be very high, and the amount of so-called "clean" money [net earnings] as not very good:

The money, that is. Because if there was a job here, I'm sure I would not do this [go abroad]. For sure.... So, I'm sure that I would not go. Sorry.

When discussing wage advantages, we should mention one of the additional advantages; namely, the Austrian pension. Obtaining a pension from abroad is an important element in the calculations of care workers, which is why the legality of their work abroad is an important question. Is it declared to the public authorities? During our interviews, several respondents expressed disappointment about the fact that they would have been due an Austrian pension a long time ago if they had not started to work illegally. More interviewees reported that after five years of 
employment in Austria they expected a pension of around 30-60 euros per month, which increases in proportion to the number of years of employment.

\section{Constrained labour and becoming uprooted}

Mahua Sarkar has written a very important study on Bangladeshi migrant workers working abroad in which migratory processes and various institutional processes blur the line between free labour and forced labour (Sarkar 2017). It seems that East European women are also reporting about how they have become uprooted and how this has led to "voluntary" labour abroad.

The narratives of Csenge, Anna, and Katinka have already indicated the role of an accumulation of disadvantages produced by the transition to capitalism, and during their migration stories they return to describing the shock caused by the change of regime and to the radical transformation of local economic structures at that time. The massive corporate bankruptcies, particularly in the textile industry, and the system of unfavourable loans and other structural constraints all point to the external mechanisms of the globalization process.

Katinka draws attention to the importance of her former employment in a glove factory in the 1980s, which, though it damaged her eyes, still provided her with a stable livelihood. In the early 1990s the wages and opportunities at the factory were declining due to huge global competition. It is also apparent that after this episode the interviewee could not really recover and got into serious difficulties as a worker, even leading to her exclusion from the social benefit system.

I commuted to the glove factory to work for 23 years. Then I could not tolerate this physically, my eyes went really bad and my husband said that I should not continue. Actually, I had been already working at home, I received a [sewing] machine at home, but in the countryside there were things to do in the vegetable garden during the day, there was the family, there were two little children - three-and-a-half-year-old twins - and then my husband said there was a bus attendant job in the neighbouring village. That the kindergarten kids needed to be watched, and my husband told me to go there and do it, it would be better. I listened to him, hmmm, but the money was too little, they counted only four hours, and the money was not enough. Then a German flower shop opened, and I went there, and then it went bankrupt, and I could not find a job because I was over forty, with a rural background, and I was not hired any more. Then I had a long period of unemployment and claiming benefits. When this (Inter)City railway job started, I came here, I got hired to clean; I had a permanent nightshift here, while we were getting divorced. And then we got the money in hand and I did not pay the tax on it, but I invested it in the house... Then they dismissed me saying that they could not hire entrepreneurs who had public debts. But everyone had public debt! [smiles]. Ahm... so, not just me, almost everyone had. And I could not get any benefits like that, because entrepreneurs do not receive any benefits. 
Then there were some occasional jobs such as cleaning in the construction industry, illegally.... So, I was sent away. And this friend told me, she convinced me to leave from here because, because I would see how good it can be. (Katinka, 61)

It is also important to know that the shock of the regime change led to an earlier migration attempt in Katinka's life history and also in other cases, but paying agency fees proved to be problematic at that point and migration was not accomplished.

This early experiment also shows that at that time the "infrastructure of migration" was relatively undeveloped compared to the circumstances today (Xiang - Lindquist 2014).

This early attempt occurred during the first wave of emigration that started in the second half of the 1980s and which appears in the Austrian and mainly German statistics (Melegh 2015), and it was just an initial reaction. The initial shock was not enough to produce migration in the sense of the "uprooting" process described by world system theory (Sassen 1988, Massey 1993). It happened more slowly, when the "struggle," the almost constant crisis caused by disadvantageous circumstances, became permanent, at least according to the testimony of these interviewees.

Fanni also talks about a similar shock during the change of the regime and also points at an additional crisis in 2008 when she launched a small business with her husband, and how the related family crisis led to the decision to migrate for work:

Well, I was working as an administrator at the state farm in B. before I finished... in '70..., from 1974, I worked there for 17 years, then the farm, privatization came, then it finished up unfortunately. We would have never believed that such a big state farm, where 1000 people were employed, could suddenly... this was not so, we did not believe that it was happening. We were even happy that it was so good for us, we did not have to go to work, you were unemployed for a bit, but then you got the surprise that this was it - it really is, what will happen now? A few months, and then what will happen? Because if you were on the treadmill, it was so good, you rested a bit, you were at home - and afterwards? It was a great shock. (Fanni, 60)

It can be stated that both the interviewees report and their biographies show that the radical transformation of the external environment at the time of the collapse of state socialism in the given migratory space uprooted people from their former stable positions and resulted in a long-lasting period of insecurity as reported in their interviews. We can also call this process becoming "disembedded" from a customary and stable situation, as Hann would call it on the basis of the conceptual framework of Karl Polanyi (Hann 2018). This feeling of being uprooted for a longer period can lead to such narrations as the former ones, as opposed to stable life histories. In these cases, migration can be interpreted as a long-term response to insecurity. In other words, transformations driven externally from the point of view of the local community are taken into account and perceived in the narrations. According to the interviewees, the latter created constraints over time, which processes may 
have involved several coercive mechanisms, at least according to the interrelations observed in the interviews.

In the interviews, one of these mechanisms of insecurity (as we have already seen above) is the decrease in wages and even the non-payment of wages: These problems, together with the deterioration of other circumstances (debts, deterioration in health, etc.), actually led to a pre-migration crisis which cannot be interpreted as migration generated by low wages, but by constraints of livelihoods and precarious states (see for example Szépe 2012). This is well illustrated by Ilona's case. She describes in her own words how, following the example of her sister, she escaped from a very hard situation.

I went abroad after working in catering, then my husband became very ill and had to sell the business after 23 years; that was the [breaking] point, and after that it was hard to find a job again. And then, I was originally from the village, but the point of the whole thing was that we were searching, and then I settled in a place, in a (good) bakery. I was a shop assistant, a bakery shop assistant, so I worked like a slave... since I did not get paid, I did not get days off, I did not get money on days I did not work, so I thought that was it. In the meantime, an acquaintance said that one could go to work to Germany, as I had intended to do before, and at the age of 50 I went to Germany to work on a 'Hof'. Afterwards, I said I would not go anymore, as it was slavery at that time and it was very, very difficult. I lost 24 pounds [in weight] in the three months, I broke my knees, so long, it did not matter, it was over, and then my sister who was already working in Germany as a nurse [carer] said 'Ili, this money could be earned more easily' (hmmm), and then I started to work as a nurse. (Ilona, 57)

In this case, the escape was from one vulnerable situation to another, when the interviewee engaged in care-work after experiencing very harsh working conditions.

Similarly, Diana interprets her migration in the 1990s as a case of being hit by a crisis. For her, the constraint was the crash of the social system following the introduction of the so-called Bokros package, named after the minister of finance of that time. During this period of "shock therapy," certain stable elements of the social welfare programs were cut or reformulated. Therefore Diana, who slowly became an agent organizing care-work, explained the changes in her migration steps and commuting in relation to the emerging economic hardships. She also confirms this from her role as an agent who made use of these factors:

Because unfortunately in Hungary, no matter how much you work, you cannot make enough money. I just don't wonder that many of them leave their home country, and many of them just wander, which is a very bad thing. They will not come back, because if they move out, the whole family will move out. (Diana, 41)

According to Diana, it is not wage differentials and wage maximization that matter, but the fact that financial insecurity leads to mass migration. Feelings of economic insecurity also become dominant in the interviews when interviewees report to struggling with other crises, the most important of these being connected 
to the family. Vivien interprets her own story quite dramatically and recounts how she was forced to leave not only because of vulnerability and insecurity at work, but also due to a sudden family crisis.

Well, it's been a long time since one bought a house in cash, it's impossible, we don't earn so much in today's world. I had a job in the catering industry, I worked down here in the pub for a while, also before and after my daughter's birth, but on the one hand working conditions changed a lot, the salary became very low. I was almost never at home - as you might know, in catering there are no weekends, no holidays, nothing - I was not at home, I was not paid, and in the end I had to do everything, so the line had been crossed. I quit, but work was needed. Then, my mom. She was an alcoholic and she was in very bad shape so I took care of her, but she needed support, although she was working at the local government, but it was not enough for anything. Then I worked for Eckerle for a while, this company produced gadgets, but I did not feel okay, so I finished after three months. Meanwhile, my mother moved away because I wanted to control her drinking, but she drank, so we did not understand each other, and when she moved home she managed to get so drunk that she died. So, to tell the truth, I had no money for the funeral, so one week after her death I left, because there was no choice, I had to pay for the funeral, and when I came back after the first two weeks, we buried her. So, I left to go abroad exactly because there was nothing for covering this. (Vivien, 27)

In this case, additional factors, namely former migration patterns, social ties and former migratory networks, played a role. Before her migration Vivien's mother had also worked harvesting asparagus in Germany, and her brother had worked abroad as a stonemason. This explains why these family members could leave in the given situation, but not others (Portes 1995, Portes - Böröcz 1989, Gödri 2010, Blaskó Gödri 2014). Thus the case involved not only a need to reduce costs, but migration was probably one of the (often postponed) solutions. Almost all the interviewees drew attention to the role of historical and ethnic networks. These also involve regional characteristics, such as the Swabian-German relations that already existed during the time of state socialism and which impacted the lives of interviewees (Blaskó - Gödri 2014, Feischmidt - Zakariás 2010, Váradi et al. 2017, Gábriel 2018). Thus ethnic and migratory patterns in the migratory processes are also major structural factors in migration, which according to the interviewees become factors with a direct impact in serious crisis situations (Feischmidt - Zakariás 2010). In fact, such a coexistence and correlation of factors can be observed in other cases of financial insecurity; for example, when crisis occurs due to debt.

Similar to other factors, the crisis can also be connected to the factor of age, as the interviewees repeatedly indicated that they could not find any work at over 50 years of age. Age-related discrimination was also a factor, in their opinion.

Divorce plays a role in many cases... so if someone has just divorced, many of them are with children, they have to be cared for, and it is typical that the children of 
caregivers [who go abroad] are the youngest children, who are in the third or fourth year [of school]. I heard about one who was two years old. I have a care-worker now where the child is younger, another is starting school now. Variable. Variable. So this is a problem. The older age group is just before retirement and they cannot get a job in Hungary at the age of 55-56. (Diana, 41)

To sum up, the above interviewees do not portray themselves as free and rational decision makers. In their reports family crises are the key factors, related to various wider structural causes and changes (see also Váradi et al. 2017). It is important to note that the "crisis narratives" in themselves could also be a legitimating tool in a discursive space that does not support migration, as found in earlier research (Kovács -Melegh 2000, Turai 2018). It can also be argued that migrant workers try to justify their moves through such crisis narratives. This fact may also play a role, but it must be pointed out that the above-mentioned coexistence of multiple biographical events suggests that these crises are not (or only partially) re-evaluations, or means of legitimizing decisions in hindsight, but refer to real and serious hardship.

\section{Ignoring costs, and the family economy}

One of the last elements in the micro economics of migration in any given space is that interviewees often ignore a significant number of costs (e.g. they do not take into account the fact that they are providing a 24-hour service when they talk about wages), or they do not associate their work with other "costs" and "benefits"; namely, their micro-economic calculations are not complete. They treat the fees of brokers relatively consciously, and the receiving families or agents handle insurance and travel expenses.

One of the most important elements regarding the "forgetting" of costs is that interviewees rarely mention the fact that they are not able to take their family members with them, and members cannot get jobs in the same place. This situation is largely incompatible with information about wages and conditions, as the agent of the caregivers explains:

Many people call me, saying that 'I want to do care work, but I want to go with my husband.' Of course, I'm not partner to these things. First, I don't deal with organizing this, that someone gets a job in the same city, in the same place. I would like to tell you that we recruit people for this intensive care through partnerships. In Austria we send people directly to families. So I cannot find a job for someone's husband, and in such cases I tell them [the applicants] that they should try elsewhere. There is no way to do that... We send people abroad, not families. (Diana, 41)

The difficulty which is touched upon above indicates that these costs are not accounted for but become a part of familial self-exploitation, in the sense that Chayanov used the term in the case of peasant economies (Chayanov 1966). If taken into account these costs would significantly reduce the "competitiveness" of net 
salaries of 140-240,000 forints which migrant workers try to boost via "forgetting" the time they spend at home between shifts. The dilemma of how to reconcile one's duty to care for one's own dependent parents with care work abroad is regularly seen in the literature, but often forgotten.

Similarly, work-related health problems and their consequences can also be added to the costs. Serious work-related acute and chronic illnesses are reported by the interviewees, although their consequences are scarcely mentioned and they are not included on the migratory balance sheet.

Katinka lived in a house in a forest with her patient, where she had to work and sleep in a temperature of $13^{\circ} \mathrm{C}$ due to poor insulation. The cold temperatures played a role in the emergence of inflammation and benign tumors, which trouble her during her everyday life. Réka talks about a herniated disk and recurrent panic disorder:

Due to necessity... In 2005, I went to Tirol, I worked in a four-star hotel as a maid. In October 2009, I went home, (I was) burnt out, sick, with a herniated disk. I could not get a job at home, I set up a business, I made frames and cleaned with my mother, the two of us. This was my job for two years. Then the jobs ran out because people saved money when they could. I've been working my whole life and I won't be a parasite... Then in 2008 I changed my working schedule, which was then not seven months, but only three-and-a-half or four-and-a-half, but in 2007 it became clear that I had a panic disorder due to stress. But at that time it didn't occur to me that a doctor would be needed, and I had no idea at all that this was the case, [that this was why I was getting dizzy], I got sick: I slept and kept on going... (Réka, 54)

To sum up, some of the costs and difficulties of working abroad arise from sharing in the household. The leaving behind of one's own family is constantly forgotten, or the situation is considered only as the difficult and inevitable consequence of the migration situation. In other words, the strengths of family relationships, the work itself, the distinctions between work and health impacts handling the two separately all hide some of the costs and thus make jobs abroad less "profitable." This "ignorance" of interviewees was also due not only to family microeconomics but also to the desire to show that that they were being successful in managing very difficult situations or unprivileged social positions.

\section{The organization and institutionalization of labor migration among care workers}

One of the most important issues concerning transnational care work is the fact that among many migrants who work abroad, including many of our respondents, the arrangements do not involve free, non-commodified-type agreements between two households, where one household shares its income with the another to get certain activities done. Therefore, such care-work it is not a "traditional" form of work, and is distinct from the classical, commodified wage labour described by Marx or Karl 
Polanyi (Polanyi 1844/2001, 76; Szigeti 2017, Turai 2016). It involves transactions not only in the informal market or outside of the market, but a form of institutionalized market where very often, and very importantly, a profit-orientated agency network utilizes wage differentials and the welfare benefits given by the receiving state, and brokers obtain a significant share of the rent (unearned income) from migration. Principally, it is the receiving state and booming recruitment activity that capitalize on hierarchical wage relations and extract the rent from a globally unequal system. Thus this activity and the activity providers become (using Polany's term) fictitious commodities and part of the multiverse of global work (see for the role of "migration infrastructure," Xiang - Lindquist 2014, 123-125; for global work, van der Linden Roth 2013, 448, 457, 458; for fictitious commodities, Polanyi 1944/2001, 75, 79). Thus, from the perspective of the theory of migration, this mass process cannot be described as merely a mechanical product of the decisions of migrants, as assumed by scholars that promote neoclassical models to explain migration. In many respects, the process is driven to a large extent by demand, and a specific set of agents; namely, it should be seen as a type of segmented labour market model (Parrenas 2001, Turai 2018, Massey 1993, Gábriel 2018). Our interview with an agent illuminates the process of objectification ("human trafficking") and also the logic of payments, which reveals (through a process of magnifying benefits again) that a monthly wage of only 700 euros may be obtained (based on 24-hour service for the period of work), after travel costs and social contributions in the host country are paid for. The following is what our agent interviewee says about this process:

In Austria in competing companies people have been quasi-trafficked; they treat nurses [carers] like... they mediate, and they pay wages that simply [would not be paid] in the normal process of labor recruitment.

It should be noted that on a macro level, it is also clear that, due to uneven exchange between the two countries, Austria skims off a significant social transfer as it earns hundreds of euros per month and per capita per migrant worker from the Austrian social and retirement scheme, as under the relevant rules hardly any benefits must be paid to them (five years of employment and a higher contribution into the system are required before any serious retirement benefits can be obtained). ${ }^{6}$ Thus, some part of the financial payment made by the host state (550 - 1100 euros per month) is also recouped by the host state, while due to "care distraction," vacant care worker positions, and absent roles within the family in the sending countries, deficiencies may arise in connection with care (Turai 2018, 182-190).

The interviews with the migrant labour agent are also very informative as the agent also "forgets" to mention her own fees, although these sums can be huge. In many cases, at least in this migratory space, these costs are paid by the host family, but it frequently occurs that the workers themselves have to pay 100-200 euros per

6 On a macro level see: https://g7.24.hu/elet/20180102/az-osztrakok-kiszamoltak-mennyit-hoz-nekik-egy-bevandorlo-esmennyit-visz-egy-menekult/ (Last download: 2018.05.27) 
month (110,000 forints annually), or 10 percent of their salary. This sum is usually not included in the often-mentioned net salary of 700 euros per month, but it is sometimes debited from the net wage. In exchange, the interviewees receive not only addresses from the agent but they are also assured that in the event of their or their shift-partner's illness (absence), they will not need to organize a substitute. Thus, the situation clearly shows the existence of a secondary, private redistribution system, as national social services do not cover these labour relations.

\section{Competition among labour migrant groups}

Based on the interviews, we can state that the related wages are only relatively high before the full range of accounted- and not accounted-for ("forgotten") costs are considered (24-hour shifts, and all the physical and psychological hardships, particularly among aging, 50-60 year-old women). One of the reasons for this is that, in the given migratory space, host families are likely to try to manage within the limits of the state benefit they receive for elderly care as described above (i.e. they try to keep the gross labour costs of care work to less than 1100 euros), and to finance only the smallest part of the cost of care from their own pockets. Obviously, the situation is variable, and while there are families which treat care-workers humanely and fairly, there are also very unpleasant families that try to save every penny. Via this benefit system the Austrian state generates demand for migrant labour from low-income countries; labour that is also an important and indispensable part of the social care system in the sending society. Therefore, the process involves the conscious, statesupported use of wage differences, so we should not speak about the functioning of a neoclassical market model of supply and demand. Without this benefit-driven demand, there would not be such massive migration within the given migratory space.

Wages are kept low due to another mechanism as well. This is wage competition between various labour migrant groups. Competition is linked to the employment of cultural prejudices against "problematic" groups of workers (regarding such competition, see Feischmidt 2004 and Feischmidt - Zakariás 2011; with a focus on Eastern European care givers see Turai 2018, 11). The cost of this competition is borne by the migrant groups as a from of externality of the market system, and can involve direct financial losses for the migrant labourers. Moreover, financial disadvantages can also be indirect: in such fragmented labour market segments, rivalry certainly reduces the ability of migrants to enforce related interests concerning working conditions in a diverse and fragmented social space (Hoerder et al. 2015, 5-20). This rivalry, which reduces not only employees' but also agents' commission and income, was explained by the agent we interviewed as follows:

I have the minimum wage here, I do not even get this; last month, this month my salary was 79,000 forints, and I have been doing this for five years. This is not going well, even with us [agents] anymore, so you have to know that we - from our 
partner company's commission, and the families... the family will pay us the monthly commission as long as our service is used. So many families, many families would be needed to be make a profit, and then after taxation I would be able to make a living. Because if I earn ten million (forints), half of it goes to the state as tax. And how can you produce ten million extra a year, when I need almost 500,000 forints a year to rent [the office]? Forty-five thousand forints is the rental fee for this office that needs to be paid. The wages have to be paid, I pay almost 100,000 forints in social contributions each month. Then, the wages and other things, I count all of this... to have ten million extra, I would need so many families. There is a great deal of competition, as I said, a good deal of competition, it's very competitive. Well, nearly 400 companies are registered in Austria, not to mention the Polish, and I am not speaking about the Romanians, Bulgarians, Croatians, and Hungarians, these five countries, neighbouring countries, with hundreds of companies, recruitment companies specialized only in elderly care. In Romania, in only one county, we have less than a quarter [of employees] in five counties than in Romania from one county. There are plenty of agencies, lots of people who deal only with elderly care. They mean competition not only for us as a company, but also for the employees, both for the employers and the employees. So the Slovaks, Polish, Romanians are the biggest competitors in the field of 24-hour care in Germany. (Diana, 41)

Beyond the "normal" entrepreneurial complaints about costs and the lack of profit, we can clearly see that there is a need to increase the number of clients as much as possible and that the number of competing agencies and the labor force they control serves as a factor in controlling wages. This section of the interviews gave clear signs that one of the factors that maintains high levels of migration is the development of the "migration infrastructure" and the dramatic increase in agencies, as Xiang and Lindquist also argue concerning this era of globalization (Xiang - Lindquist 2014, 123-125). This situation is also recognized by the interviewees.

A care-giver also talked about the same phenomenon. They put it the following way: Then Ukrainians come, Poles, there are a lot of Poles out there, Romanian girls, Romanian girls undertake [this work] for very little money, because there is absolutely no opportunity to work in Romania. (Fanni, 60)

Due to the institutionalization of this competition it is not surprising that interviewees also feel that their position is important to them. This competitive struggle and its ideology are well illustrated by the fact that almost every interviewee talked about the refugees who had appeared in their destination space in a particularly negative way. The disapproving attitudes in the interviews were not only due to the perceived or actual social costs of people arriving from elsewhere, but also originated in perceptions about work ethics and the hierarchical position assigned by host society to caregiver migrants and incoming groups in relation to the locals. Nonetheless, the above-described political economic mechanisms are not necessarily related to the perceived positional insecurity of the East European migrant workers. Lídia, one of 
the most positive workers who looked for nice places where she could work outside of home, says the following:

I do not really understand this now. Everyone is already coming. It is not true that all of them are refugees due to wars. And they have so much money, and I can see that in Austria. There, there are a lot of them in Leoben, and I was there as the middleman called [am asylum seeker] to help a stonemason, because they live there and were moved there. He [the asylum seeker] said he receives meals all day, receives breakfast, lunch and snacks, gets coffee, gets five euros, and just something; he's a waiter, he does not work. (...) It's awful that they're loud, we see them, they are moved into such large houses - I do not meet them by the way, but we can see them there. And they're really grumbling there, because they have got smartphones, they get a flat, but not any kind of apartment but a big detached house, their children get their food in the school for free, and the families are supposed to get 1,500 euros of pocket money.

The interviewee is not worried about actual competition with her, but just about the welfare benefits the asylum seekers receive (i.e. the rents they are required to share).

Sometimes the link between feeling "disembedded" and complaints about "refugees" is apparent. Réka, representing one of the interviewees who has encountered a lot of hardship in terms of health, family and jobs, quite openly links the local welfare system to support for refugees, which also shows the rivalry among the groups. In addition, she also involves her hardships in her complaints.

Well, if we let them in, Hungarian woman will start to think about how many babies they will have to deliver.... Many of them cannot even read or write, what will happen if they start to reproduce themselves? Let's see, these refugees, they come with four or five children, these children must be fed, dressed, educated. I almost died when I tried to educate my two children by myself. Should I work for others' children?! The Austrian pension has not increased, they raised the Austrian pension only by $0.8 \%$, hundreds of euros a month. For one person. Who would like to work to support them? Come on! (Réka, 54)

To sum up, transnational elderly care is organized as part of an institutionalized, hierarchical competition which significantly determines the wage and cost conditions of care work, and the type of demand that is generated. These institutional frameworks are constantly influencing and at the same time sustaining and facilitating the process of mass migration, which, as such, can hardly be thought of as the mechanical result of aggregated rational/welfare decisions, as we demonstrate through our interviews and the reactions of interviewees.

\section{Conclusions}

The interview texts we have analysed are rich sources for understanding how interviewees construct their own very complex perspectives of migration and work 
abroad, which are reactions to cultural patterns and their own life histories embedded in larger-scale social changes. In our qualitative sociological research we have tried to understand and identify the internal mechanisms of these "ideational" processes as complex reactions to past and present circumstances. We have also tried to show what new perspectives need further analysis on a larger scale - or should involve going beyond interviews - to obtain a fuller reconstruction of the process itself.

As evidence from the interviews indicates, the short-term circular migrant labour of care-worker commuters is often embedded into perceptions of a highly institutionalized hierarchical order within historical structures and processes and in gender-fragmented migratory spaces. Even if the interviewees dwell on numerous labour-market-related or familial crises most of them do not see themselves as individuals seeking benefits in a rational manner. The perception of making rational choice plays a role only when the interviewees have memories of a longer-term, stable job. In other words there were only a few interruptions in the employment history they recall. Thus, on the basis of the interviews we conducted, the decisions themselves are presented as being more complex than neoclassical theory assumes, suggesting that wider, historically developing structural causes and social changes may also play a major role by laying the ground for socially contextualized migratory decisions. The interviews suggest that when analyzing such processes it is pertinent to look at longer-term historical causes of migration and possibly even at the structural changes of previous decades. If interviewees report to having experienced multiple crises in their life (work, family, debt, etc.), and this knowledge is coupled with a pattern of outmigration by other family members or by individuals from a closer network then it seems, we need to take a longer term historical perspective. With further research we may thus develop a new understanding of this type of migration and constrained short-term cyclical migrant labour and we can reconstruct the experience of abandoned workers in post state socialist Hungary.

The targeted group itself might be important, since it is likely that former working class people, unskilled and semi-skilled workers in the various declining professions deserve special attention. Qualitative research can only argue that a systematic connection is possible between the effects of globalization and migration. Thus, some of the women who are leaving a labour market that is declining due to globalization occasionally try to find employment in the service industries, while eventually they enter into this global labour market through utilizing certain family, ethnic and local patterns and relationships, especially when after a longer and more stable period they become vulnerable financially for a longer period of time. The issue is not the coexistence of different forms of work and inequalities, as suggested by the critical literature on global labour (van der Linden 2013). Here, in the given migratory space, these different forms of work and the related inequalities can be linked by a historical logic, as we learn from the interviews. The migrant women we interviewed had stable jobs in late state socialism which were later ruined by the globalization of the textile 
industry or other declining or very competitive service industries, and then a longer struggle started. Some of these workers have moved slowly from the marginalized sectors into global care work: this is how they become transnational actors.

This painful process of structural transformation could be the space in which individual interviewees manoeuvre. The changes they have experienced and the forces uprooting them produce a lot of bitterness among them, whilst the transnational life and entering the global market have also brought inner joy and satisfaction to these women. In the meanwhile, their situation has only partially improved, and their vulnerability may have just been restructured, thus overall we are witnessing the personal records of the reproduction of various subordinated positions.

We could also reconstruct from these interviews that some of the costs of these decisions or work abroad are hidden even to the interviewees themselves, which situation we hypothesized to be linked to the structures of family economies which follow a different logic than "profit-making" organizations. Their prime motive of the former can thus be the level of subjectively felt self-exploitation as described by Chayanov and as originally applied to peasant families. But it seems that migrant labour to large extent controlled and organized by the family and not the individual may have some elements of the model described by Chayanov. This model and several other mechanisms (such as migrants trying to show the positive outcome of migration, or even an improvements of status) can lead to the "suppression" of some costs which makes the analyzed decisions even less "rational" in an individualist sense. Thus, on the basis of our research it can be claimed that the household economics model may be a key model in such analysis as middle aged and elderly family members also react to a combination of individual and societal level changes, including declining health, various family crises involving divorce and debt, and the loss of jobs. Along these linked cycles they manoeuvre, most probably trying to minimize their losses and risks as far they are able to do so in a highly competitive sphere of work. Surely this situation needs further research using data and observations that goes beyond the interviews we have analyzed in a specific region.

\section{References}

Blaskó Zs. - Gödri I. (2014): Kivándorlás Magyarországról: szelekció és célországválasztás az új migránsok körében. Demográfia, 57 (4): 271-307.

Burawoy M. (1987): The Limits of Wright's Analytical Marxism and an Alternative. Berkeley Journal of Sociology, 32: 51-72.

Chayanov A. (1966): The Theory of Peasant Economy. Eds. Thorner, D., Kerblay, B. H., Smith, R. E. F. Manchester: Manchester University Press.

Durst J. (2013): „It's better to be a Gypsy in Canada than being a Hungarian in Hungary”: The „new wave” of Roma migration. In Vidra Zs. (ed.): Roma migration 
to and from Canada: The Czech, Hungarian and Slovak case. Budapest: CEU-CPS, 203-248.

Feischmidt M. (2004): A határ és a román stigma. In Kovács N., Osvát A., Szarka L. (eds.): Tér és terep: Tanulmányok az etnicitás és az identitás kérdésköréből. Az MTA Kisebbségkutató Intézetének évkönyve; 3. Budapest: Akadémiai Kiadó, 43-58.

Feischmidt M. - Zakariás I. (2010): Migráció és etnicitás - A mobilitás formái és politikái nemzeti és transznacionális térben. In Feischmidt M. (ed.): Etnicitás. Különbségteremtő társadalom. Budapest: Gondolat, MTA Kisebbségkutató Intézet 2010.

Gábriel D. (2018): A Magyarországról Ausztriába irányuló idôsgondozói migráció Egy kvalitatív kutatás eredményei a dél-baranyai térségből induló idősgondozói migráció mechanizmusáról. KSH NKI Kutatási Jelentések, Budapest: KSH Népességtudományi Kutatóintézet. (In print)

Gödri I. (2010): . KSH NKI Kutatási Jelentések 89. Budapest: KSH Népességtudományi Kutatóintézet.

Hajnal L. E. (2012): Romák Kanadában. Kivándorlás Magyarországról az 1990-es évek második felétől In Sik E. (ed.) A migráció szociológiája 2. Budapest: ELTE TÁTK, 60-83.

Hareven T. K. (1982): Family Time and Industrial Time. The Relationship Between the Family and Work in a New England Industrial Community. Cambridge: Cambridge University Press.

Hann, Chris (2018): Mafia State or Populist Re-Embedding? Hungary Three Decades after Socialist Collapse. University of Essex, Mark Harvey Retirement Meeting, October 5th, 2018, Manuscript

Hárs Á. - Simon D. (2015): A munkaerö-migráció változása a kétezres években Magyarországon. Vizsgálat a munkaerő-felmérés adatai alapján. Magyar Tudományos Akadémia Közgazdaság- és Regionális Tudományi Kutatóközpont Közgazdaságtudományi Intézete, Budapesti Corvinus Egyetem Emberi Erőforrások Tanszék.

Hoerder D. - van Nederveen Meerkerk E. - Neunsinger S. (eds.) (2015): Towards a Global History of Domestic and Caregiving Workers. Leiden, The Netherlands: Brill.

Kovács É. - Melegh A. (2000): „Lehetett volna rosszabb is, mehettünk volna Amerikába is - Vándorlás történetek Erdély, Magyarország és Ausztria háromszögében. In Sik E. -Tóth J. (eds.): Diskurzusok a vándorlásról. MTA Politikai Tudományok Intézete Nemzetközi Migráció Kutatócsoport Évkönyve, 93-154.

Kovács É. - Melegh A. (2007): In a Gendered Space - Forms and Reasons of Migration and the Integration of Female Migrants. Demográfia English Edition, 50 (5): 26-59. Massey D. - Arango J. - Hugo G. - Kouaouci A. - Pellegrino A. - Taylor, J. E. (1994): An Evaluation of International Migration Theory: The North American Case. Population and Development Review, 20 (4): 699-751. 
Massey D. - Arango J. - Hugo G. - Kouaouci A. - Pellegrino A. -Taylor, J. E. (2001): A nemzetközi migráció elméletei: áttekintés és értékelés. In Sik E. (ed.) A migráció szociológiája 1. Szociális és Családügyi Minisztérium, Budapest.

McKeown A. (2004): Global Migration, 1846-1940. Journal of World History, 15 (2): 155-189.

Melegh A. (2013a): Net migration and historical development in Southeastern Europe since 1950. Hungarian Historical Review, 1 (3-4): 144-182.

Melegh A. (2013b): Diverging historical development of migration in Southeastern Europe since 1950. Working Papers on Population, Family and Welfare. No 17. Budapest: Demographic Research Institute, Hungarian Central Statistical Office.

Melegh A. - Sárosi Annamária (2015): Magyarország bekapcsolódása a migrációs folyamatokba: történeti-strukturális megközelítés. Demográfia, 58 (4): 221-265. doi: 10.21543./dem.58.4.1

Melegh A. (2016): Unequal Exchanges and the Radicalization of Demographic Nationalism in Hungary Intersections. EEJSP 2(4): 87-108. DOI: 10.17356/ ieejsp.v2i4.287 http://intersections.tk.mta.hu

Melegh A. (2017): Európa a globális migrációban 1990-2015 között az ENSZ és a Világbank statisztikái tükrében. Demografia.hu/Korfa 2017. Március XVII(1). http://demografia.hu/kiadvanyokonline/index.php/korfa/issue/view/549

Mihályi P. - Szelényi I. (2019): Rent-Seekers: Profits, Wages and Inequality. The top 20\%. Palgrave. London

Nagy B. - Krízková A. - Kanjuo-Mrčela A. (2012): A munkaerő-piaci politika hatása a nemek közötti egyenlőségre a gazdasági átalakulás és az EU csatlakozás időszakában: Csehország, Magyarország és Szlovénia összehasonlítása. Szociológiai Szemle, 22 (1): 30-60.

Obádovics Cs. - Bruder E. - Kulcsár L. (2011): A gazdasági és szociális helyzet területi egyenlőtlenségei a vidéki Magyarországon - hasonlóságok és eltérések. In Bódi F., Fábián G. (eds.): Helyi szociális ellátórendszer Magyarországon. Debrecen: Debreceni Egyetemi Kiadó. 143-157.

Parreñas S. R. (2001): Servants of Globalization Women, Migration and Domestic Work. Stanford CA: Stanford University Press.

Polanyi K. (2001) (1944): The great transformation: the political and economic origins of our time. Boston: Beacon Paperback.

Portes A. - Böröcz J. (1989): Contemporary Immigration: Theoretical Perspectives on Its Determinants and Modes of Incorporation. The International Migration Review, 23 (3): 606-630.

Portes A. (1995): Economic Sociology and the Sociology of Immigration: A Conceptual Overview. In Portes A. (ed.): Economic Sociology of Immigration - Essays on Networks, Ethnicity, and Entrepreneurship. New York: Russell Sage Foundation. 1-41.

Rosenthal G. (1993): Reconstruction of life stories: principles of selection in generating stories for narrative biographical interviews. The narrative study of lives, 1 (1): 59-91. 
Sarkar M. (2017): Constrained Labour as Instituted Process Transnational Contract Work and Circular Migration in Late Capitalism. European Journal of Sociology, 58 (1): 171-204.

Sassen S. (1988): The Mobility of Labor and Capital: A Study in International Investment and Labor Flow. Cambridge: Cambridge University Press.

Stark O. - Bloom D. E. (1985): The New Economics of Labor Migration. The American Economic Review, 75 (2): 173-178.

Szelenyi I. (2016): Pakistani guest workers in the United Arab Emirates. Demográfia English Edition, 59 (5): 5-47.

Szépe A. (2012): Prekariátus: Miért pont most és miért pont itt? Fordulat, 5 (19): 10-27. Szigeti P. (2017): Kapitalizmusfogalmak és a tőkés termelési mód elmélete. Eszmélet, 115: 1-59.

Turai T. (2016): Globális szerveződés, otthoni ápolás. A migráns gondozói szektor belső rendszere. Demográfia, 59 (2-3): 201-230.

Turai T. (2018): Kelet- és közép-európai nők a globális idősgondozói ellátórendszerben. Budapest: Balassi - MTA BTK.

United Nations, Department of Economic and Social Affairs. Population Division (2017): Trends in International Migrant Stock: The 2017 revision (United Nations database, POP/DB/MIG/Stock/Rev.2017).

United Nations Economic Commission for Europe (2016): Defining and Measuring Circular Migration 20 January 2016 https://www.unece.org/fileadmin/DAM/ stats/documents/ece/ces/bur/2016/February/14-Add1_Circular_migration.pdf accessed Conference of European statisticians

van der Linden M. - Roth K. H. (eds.) (2013): Beyond Marx: Theorising the Global Labour Relations of the Twenty-First Century. In collaboration with Max Henninger. Leiden, The Netherlands/Boston, Massachusetts: Brill. Historical Materialism Book Series.

Váradi M. M. - Durst J. - Fehér K. - Németh K. - Virág T. (2017): Kényszerú mobilitás: migrációs utak hátrányos helyzetű vidéki terekben. Socio.hu, 3 (25): 25-46.

Xiang B. - Lindquist J. (2014): Migration Infrastructure. International Migration Review, 48 (1): 122-148.

\section{Online references:}

https://g7.24.hu/elet/20180102/az-osztrakok-kiszamoltak-mennyit-hoz-nekik-egyevandorlo-es-mennyit-visz-egy-menekult/ (Last download: 2018.06.21.) 


\section{Appendix}

Table 1.: Selected demographic and employment characteristics of interviewees Interviewees in the research sample

\begin{tabular}{|c|c|c|c|c|c|}
\hline Code & Name & Age & Marital status & Shift Rotation & Status \\
\hline D01 & Anna & 53 & Married & 4 weeks & Active \\
\hline D02 & Beáta & 56 & Widow & 2 weeks & Active \\
\hline D03 & Diána & 41 & Married & 2 weeks & $\begin{array}{c}\text { Manager, former } \\
\text { care-worker }\end{array}$ \\
\hline D04 & Gáspár & 56 & Married & - & Husband \\
\hline D05 & Csenge & 74 & Widow & 4 weeks & Former care-worker \\
\hline D06 & Katinka & 61 & Divorced & 4 weeks & Active \\
\hline D07 & Ilona & 57 & Married & 4 weeks & Intermittent \\
\hline D08 & Lídia & 67 & Married & 2 weeks & Active \\
\hline D09 & Franciska & 43 & In relationship & 2 weeks & Intermittent \\
\hline D10 & László & 73 & Married & - & Husband \\
\hline G01 & Juliska & 62 & Widow & 4 weeks & Active \\
\hline G02 & Timea & 48 & Divorced & 4 weeks & Active \\
\hline G03 & Vivien & 27 & In relationship & 2 weeks & Former care-worker \\
\hline G04 & Réka & 54 & Divorced & 2 weeks & Active \\
\hline G05 & Fanni & 60 & Married & 4 weeks & Intermittent \\
\hline $\mathrm{A} 01$ & Borbála & 68 & Married & 4 weeks & Active \\
\hline $\mathrm{A} 02$ & József & 74 & Married & - & Husband \\
\hline $\mathrm{H} 01$ & Margit & 60 & Married & 3 months & Active \\
\hline $\mathrm{H} 02$ & Ferenc & 61 & Married & - & Husband \\
\hline R01 & Emma & 68 & Divorced & 2 weeks & Former care-worker \\
\hline E01 & Edina & 57 & Divorced & 2 weeks & Active \\
\hline
\end{tabular}


Table 2: Wages and some of the reported costs of care workers employed abroad Wages earned abroad, and reported costs of labor migration

\begin{tabular}{|c|c|c|c|c|c|}
\hline Code & Wage abroad & Travel expenses & Commission fee & $\begin{array}{c}\text { Contributions } \\
\text { (to state) paid } \\
\text { abroad }\end{array}$ & $\begin{array}{c}\text { Total amount } \\
\text { after deductions } \\
\text { (as calculated by } \\
\text { interviewee) }\end{array}$ \\
\hline D01 & $\begin{array}{c}1596 € / 4 \text { weeks } \\
(57 € / \text { day })\end{array}$ & $\begin{array}{l}95 € / \text { each way, } \\
\text { pays for herself }\end{array}$ & None & $\begin{array}{c}570 € / \text { three- } \\
\text { months' social } \\
\text { security (pays for } \\
\text { herself) }\end{array}$ & $900 €$ \\
\hline D02 & Not mentioned & $\begin{array}{c}60 € / \text { each way, } \\
\text { family pays }\end{array}$ & Not mentioned & $\begin{array}{l}\text { social security } \\
\text { (family pays) }\end{array}$ & Not known \\
\hline D03 & $\begin{array}{c}\text { clients: } 770 € \\
\text { minimum/2 } \\
\text { weeks }\end{array}$ & Pays for herself & Not mentioned & $\begin{array}{l}\text { social security } \\
\text { (paid for herself) }\end{array}$ & Not counted \\
\hline D05 & $1200 € / 4$ weeks & Family paid & Not mentioned & Not mentioned & Not counted \\
\hline D06 & $\begin{array}{c}1100 € / 4 \text { weeks } \\
(40 € / \text { day })\end{array}$ & Family pays & $\begin{array}{l}180 \text { euros, family } \\
\text { pays to the } \\
\text { agent. } 250-400 € \\
\text { for one offer }\end{array}$ & Not mentioned & $150,000 \mathrm{Ft}$ \\
\hline D07 & Not mentioned & Not mentioned & $10 \%$ of salary & Not mentioned & Not known \\
\hline D08 & $700 € / 2$ weeks & Family pays & Not mentioned & $\begin{array}{c}182 € / \text { month } \\
\text { social security } \\
\text { (family pays) }\end{array}$ & $700 €$ \\
\hline D09 & Not mentioned & Family pays & Not mentioned & Not mentioned & Not known \\
\hline G01 & Not mentioned & Pays for herself & Not mentioned & $\begin{array}{l}\text { Non-legal (no } \\
\text { social security) }\end{array}$ & Not known \\
\hline $\mathrm{G} 02$ & $1000 € / 4$ weeks & Family pays & $100 € /$ month & Not mentioned & $900 €$ \\
\hline $\mathrm{G} 03$ & $700 € / 2$ weeks & Pays for herself & Not mentioned & Not mentioned & Not counted \\
\hline G04 & $\begin{array}{l}\text { Germany: } 1200 \\
€ \text {, then Austria: } \\
1030 € / 2 \text { weeks }\end{array}$ & $100 € /$ way & $108,000 \mathrm{Ft} /$ year & $\begin{array}{c}200 € / \text { month } \\
\text { social security } \\
\text { (pays for herself) }\end{array}$ & $700 €$ \\
\hline G05 & Not mentioned & Not mentioned & Not mentioned & No social security & Not known \\
\hline $\mathrm{A} 01$ & $\begin{array}{c}1500-1600 € / 4 \\
\text { weeks }\end{array}$ & Pays for herself & None & No social security & Not counted \\
\hline $\mathrm{H} 01$ & $800 € /$ not known & Family pays & None & No social security & Not counted \\
\hline R01 & Not mentioned & Pays for herself & Not mentioned & Not mentioned & Not known \\
\hline E01 & Not mentioned & Not mentioned & Not mentioned & Not mentioned & Not known \\
\hline
\end{tabular}

